\title{
Response of Potus Plants (Epipremnum Aureum) to Irrigation with Drainage Water of Ornamental Fish Basins and Magnesium Sulphate as Foliar Fertilizer
}

\author{
Sami A. Metwally ${ }^{1}$, Abdelraouf R. E. ${ }^{2}$, Abou-Leila B. H. ${ }^{2}$ \\ ${ }^{1}$ Ornamental Plant and Woody Trees Dept., Agriculture and Biology Division, National Research Centre, Dokki, Giza, Egypt \\ ${ }^{2}$ Water Relations \& Field Irrigation Dept., Agriculture and Biology Division, National Research Centre, Dokki, Giza, Egypt
}

Email address:

Dr_alisami@yahoo.com (S. A. Metwally), abdelrouf2000@yahoo.com (Abdelraouf R. E.)

\section{To cite this article:}

Sami A. Metwally, Abdelraouf R. E., Abou-Leila B. H.. Response of Potus Plants (Epipremnum Aureum) to Irrigation with Drainage Water of Ornamental Fish Basins and Magnesium Sulphate as Foliar Fertilizer. American Journal of Life Sciences. Vol. 3, No. 4, 2015 , pp. 306-310. doi: 10.11648/j.ajls.20150304.18

\begin{abstract}
This study was carried out at the laboratory of National Research Centre, Egypt during two successive seasons on 2012 and 2013 to study the response of potus plants ( Epipremnum Aureum) irrigated by drainage water of ornamental fish basins diluted with tap water (DWOFB) at the concentrations $100 \%$ DWOFB, $75 \%$ DWOFB $+25 \%$ Tap water and $50 \%$ DWOFB $+50 \%$ Tap water) and interacted with magnesium sulphate as foliar fertilizer rate (MFFR) at the concentrations MFFR1 (25 ppm) and MFFR2 $(50 \mathrm{ppm})$. The results indicated that, the plants watered with absolute fish effluent (100\% fish) single or interacted with $\mathrm{Mg} 50 \mathrm{ppm}$ performed the highest growth parameters, the highest percentage of carbohydrate and significant increase in photosynthetic pigments. The foliar application of $\mathrm{Mg} 50 \mathrm{ppm}$ had positive effect on growth parameters and significantly increases in photosynthetic pigments. The plants irrigated with fish water effluent $75 \%$ followed by $50 \%$ had the second and the third largest average growth parameters and chemical constituents respectively.
\end{abstract}

Keywords: Fish Water, Magnesium, Potus Plants (Epipremnum Aureum) and Foliar Fertilizer

\section{Introduction}

Now, Egypt is facing a lot of challenges such as the limited resources of water. There are many new sources of water, which are not well exploited in agriculture. Drainage water of fish farms is one of these important sources. Abdelraouf et al., (2014c).

Researching information about the use of fish effluent to improve household nutrition are being to show greater interest in fish farming. However recycling the drainage water of fish forming rich with organic matter for agriculture use, can improve soil quality and crop productivity (Elnwishy et al.,2006), decrease the fertilizer use which became demand affected by the prices, and the farmers education (Ebong and Ebong,2006). Research information is scanty particularly in reclaimed desert land which inherently deficient in organic matter, nutrient and trace element, Abdelraouf et al., (2014a) mentioned that using drainage water of fish ponds as new sores for irrigation for soybean crop will save $25 \%$ from minerals fertilizers under sprinkler irrigation system. Also, Abdelraouf and Hoballah, (2014b) reported that, reusing of drainage water of fish farming as a new resource for irrigation and rich with organic matter and it can improve soil quality and crops productivity and reduce the total costs of fertilizers by adding minimum doses from minerals fertilizers and sprinkler irrigation system is the best irrigation system which can be used.

Many countries have included wastewater reuse as an important dimension of water resources planning. In the more arid areas of the world, wastewater is used in agriculture, releasing high quality water supplies for potable use. This diverted attention to fish farming. However, The research aimed to come out a better irrigation water quality that would enhance soil properties, secure water resources sustainability and provide additional food security.

Aquaponics is the combined culture of fish and plants in recirculating systems. Nutrients, which are excreted directly by the fish or generated by the microbial breakdown of organic wastes, are absorbed by plants cultured hydroponically (without soil). Fish feed provides most of the nutrients required for plant growth. As the aquaculture effluent flows through the hydroponic component of the 
recirculating system, fish waste metabolites are removed by nitrification and direct uptake by the plants, thereby treating the water, which flows back to the fish-rearing component for reuse. Removal of nutrients by plants prolongs water use and minimizes discharge. Plants grow rapidly with dissolved nutrients that are excreted directly by fish or generated from the microbial breakdown of fish wastes. Dissolved nitrogen, in particular, can occur at very high levels in recirculating systems. Fish excrete waste nitrogen, in the form of ammonia, directly into the water through their gills. Bacteria convert ammonia to nitrite and then to nitrate. Aquaponic systems offer several benefits. Dissolved waste nutrients are recovered by the plants, reducing discharge to the environment and extending water use (i.e., by removing dissolved nutrients through plant uptake, the water exchange rate can be reduced). Minimizing water exchange reduces the costs of operating aquaponic systems in arid climates and heated greenhouses where water or heated water is a significant expense. Having a secondary plant crop that receives most of its required nutrients at no cost improves a system's profit potential. The daily application of fish feed provides a steady supply of nutrients to plants and thereby eliminates the need to discharge and replace depleted nutrient solutions or adjust nutrient solutions as in hydroponics. The plants remove nutrients from the culture water and eliminate the need for separate and expensive biofilters. There is a growing body of evidence that healthy plant development relies on a wide range of organic compounds in the root environment. These compounds, generated by complex biological processes involving microbial decomposition of organic matter, include vitamins, auxins, gibberellins, antibiotics, enzymes, coenzymes, amino acids, organic acids, hormones and other metabolites. Directly absorbed and assimilated by plants, these compounds stimulate growth, enhance yields, increase vitamin and mineral content, improve fruit flavor and hinder the development of pathogens. The result is reduced plant growth. (James et al., 2006).

Objective of this study was maximizing utility from drainage water of ornamental fish basins on growth characters of potus plants as example of ornamental indoor plants.

\section{Materials and Methods}

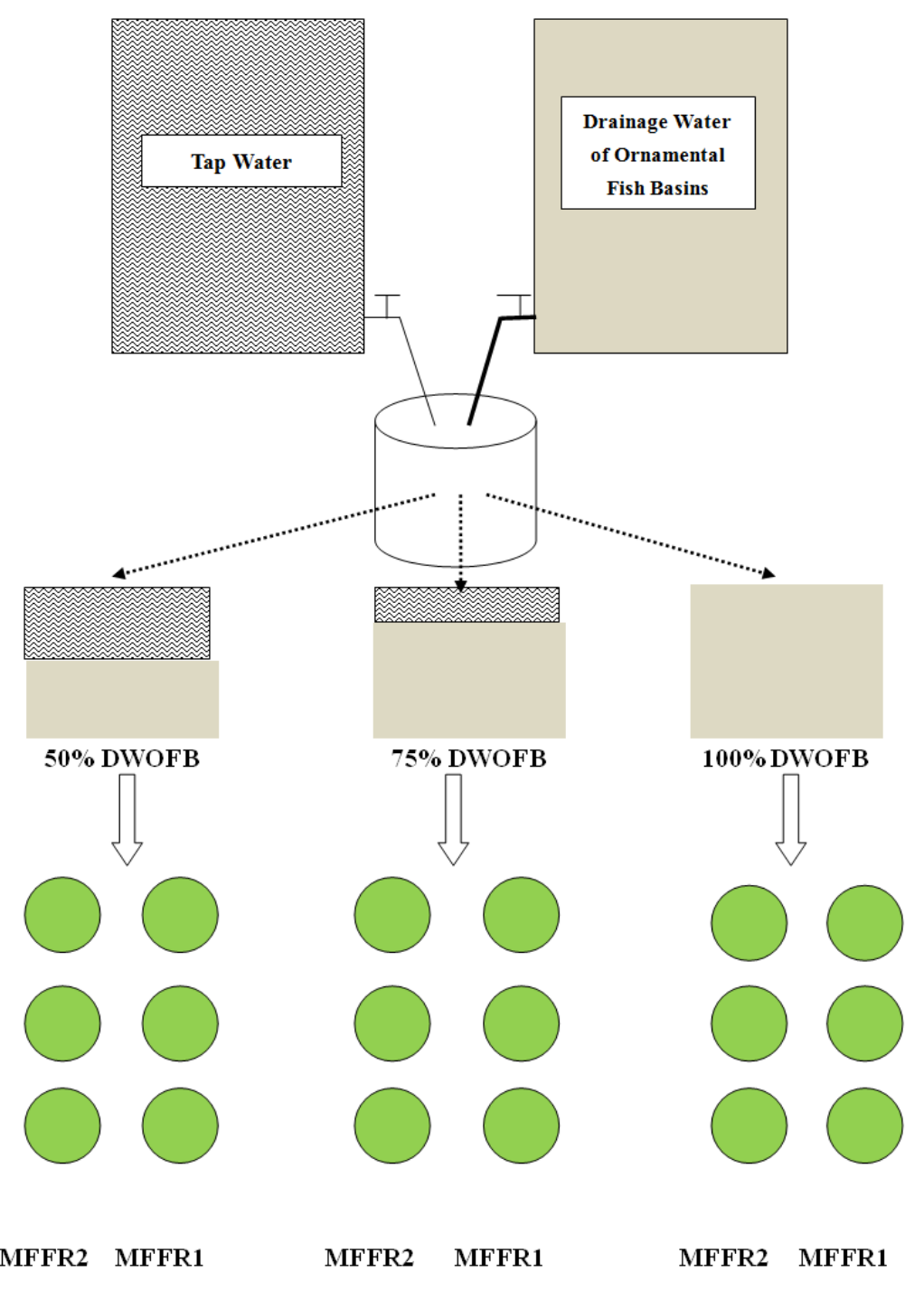

Fig. (1). Layout of Experiment Design. 
This experiment was carried out at the laboratory of National Research Centre, Dokki, Cairo, Egypt, during the two successive seasons of 2012 and 2013 to study the effect of foliar application of Mg at different doses 'MFFR' (MFFR1 25 ppm, and MFFR2 $50 \mathrm{ppm}$ ) on the growth and some chemical constituents of Potus plant irrigated with drainage water of ornamental fish basins (DWOFB). (Table1) showed some chemical analyses of the used fish irrigated water according to Cottenie et al. (1982). The experiment aims to increase the growth of potus plants grown with water of ornamental fish basins and foliated with $\mathrm{MgSo}_{4}$ for improve leaves quality

One month old homogeneous terminal cutting of potus plant were transplanting in pots $20 \mathrm{cn}^{2}$ which filled with peat moos and sandy soil $(\mathrm{V}: \mathrm{V})(1: 1)$ by volume in both seasons. The terminal cutting irrigated with tap water till rooting, and then it was subjected after 30 days from transplanting to drainage water of ornamental fish basins (DWOFB). Fish water was introduced by diluted fish water. The level of drainage water of ornamental fish basins in irrigation water blending by volume with fresh tap water contains $100 \%$ DWOFB, 75\% DWOFB + 25\% Tap water and 50\% DWOFB $+50 \%$ Tap water).The moisture content of pots kept at fixed percentage of available water. Application of $\mathrm{MgSo}_{4}$ (25 and $50 \mathrm{ppm})$ was carried out twice after 50 and 65 days from transplanting as foliar spray, the control was sprayed with tap water.

The design of the experiments was complete block design with 6 replicates. After 210 days from transplanting representative samples were taken from every treatments and the following data on the vegetative plants were recorded. The data for mean of two growing seasons was carried out according to Snedecor and Cochran (1982) and the values of least significant differences (L.S.D. at $5 \%$ level) were calculated to compare the means of different treatments.

The experiment included 6 treatments each treatment with 3 replicates. The Pump gives maximum head is $0.95 \mathrm{~m}$ and maximum discharge is $480 \mathrm{l} / \mathrm{h}$. Two factors were studied during this Experiment. First factor was irrigation by mixed drainage water of ornamental fish basins "DWOFB" (100\% DWOFB, $75 \%$ DWOFB $+25 \%$ Tap Water and $50 \%$ DWOFB $+50 \%$ Tap Water) and second factor was Magnesium Sulphate as Foliar Fertilizer Rate 'MFFR' (MFFR1 and MFFR2) and their interaction.

Layouts of experiment design and all details about the experiment design as shown as in fig. (1)

\section{Results and Discussion}

1-Effect of Irrigation by Drainage Water of Ornamental Fish Basins, $\mathrm{Mg}$ foliar spray and their interaction on the Growth Parameters of Potus Plants:

1)- Growth:

Vegetative growth of potus in Table (2) gave a negative relationship in most cases when increasing tap water in irrigation system. The highest increases in plant height, number of leaves, leaf area, fresh and dry weight were recorded in potus plants irrigated by $100 \%$ drainage water of ornamental fish basins (DWOFB). The depression on plant height, stem diameter, leaf area and leaves dry weight were when plants irrigated with 50\% (DWOFB) and 50\% tap water. In this respect it was noticed that number of leaves and root length, the differences between treatments were not enough to reach the level of significance. As for Magnesium treatments all growth parameters i-e plant height, stem diameter, leaves fresh and dry weight gradually increased as the level of $\mathrm{Mg}$ increased. However, the two levels of $\mathrm{Mg}$ did not showed a considerable difference among them on number of leaves.

The interaction between drainage water of ornamental fish basins (DWOFB) and Mg treatments on growth of potus plant were recorded in Table (2).Plant height, leaves fresh and dry weight, also, leaf area, were significantly affected by interaction. On the other hand, number of leaves, stem diameter as well as root length did not record appreciable effect.

The highest percentage of increment was recorded in plants sprayed with $50 \mathrm{ppm} \mathrm{Mg}$ and irrigated with 100\% (DWOFB). However, number of leaves and root length did not exert any significant effect.

2)- Chemical constituents :

a)- Carbohydrate

Carbohydrate percentage (Table 2) was the lowest by diluting water fish effluents to $1: 1$.The highest percentage of carbohydrate was achieved by using absolute water $100 \%$ (DWOFB).

As for $\mathrm{Mg}$ treatments (Table 2) no significant differences were obtained regarding carbohydrate percentage. On the other hand, the highest carbohydrate percentage were obtained in leaves of potus plant irrigated with $100 \%$ (DWOFB) and sprayed with $\mathrm{Mg} 50 \mathrm{ppm}$

b)- Photosynthetic Pigments

Statistical significant difference (Table 3) in photosynthetic pigments in response to irrigation with (DWOFB), where chlorophyll a, b and caratenoid, decreased significantly and gradually by increasing tap water concentration in irrigation water, however, the photosynthetic pigments were the highest by increasing $\mathrm{Mg}$ up to $50 \mathrm{ppm}$ and interacted with $100 \%$ (DWOFB)

\section{Discussion}

Our results showed that, the growth of potus plants was affected by irrigation with different concentration of fish effluent. The plant watered with absolute fish effluent performed the highest growth parameters. We can conclude from the results that, the plant grow well when watered with $100 \%$ (DWOFB) performed the highest growth parameters, because it had enough of many nutrients such as N,P and $\mathrm{K}$ in addition to some micro nutrient ( Table 1 ). Johnoson (2007) stated that nitrogen is an essential nutrient for plant growth where deficiency constant plant growth.

The plants grown with fish water (DWOFB) $75 \%$ had the second largest average growth parameters. The average of 
plants irrigated with 50\% (DWOFB) was ranked third in relation to other plants.

In this respect Khan et al (2010) had reported taller plants, thicker stems and larger leaf area for sorghum and maize with fish water effluents compared with ordinary fresh water. Also, Casmas Osti Muoneke et al (2014) reported the same results on amaranth production.

Those mean that nutrients which are exerted directly by the fish or generated by the microbial breakdown of organic waste are absorbed by plants. Fish feed provided most of the nutrient required for plant growth. Fish waste metabolites such as ammonia is removed by nitrification and direct uptake by plant (Rakocy et al (2013)).

In this respect, Casmos Ositan (2014) mentioned that, fish effluents produced higher number of leaves and taller plants of amaranth plants.

The foliar application of $\mathrm{Mg} 50 \mathrm{ppm}$ on potus plants had a positive effect on growth parameters and significantly increases photosynthetic pigments. However, magnesium is the central atom of chlorophyll molecule and plays an important non specific role in the processes of phosphate transfere. The effects of foliar application of $\mathrm{MgSo}_{4}$ might be due to their critical role in crop growth implicated in photosynthesis processes, respiration and other biochemical and physiological activities. These results are similar to those of Zeidan and Nofal (2003),El-Maghraby (2004) and Kumar et al.,(2009) and El-Met,et al.,(2011).

The results, demonstrated that, $\mathrm{Mg}$ has a role on potus growth and we need to spray it especially in the treatment of (DWOFB) $100 \%$ with the concentration of $\mathrm{Mg} 50 \mathrm{ppm}$.

Table (1). Shows some elements in the chemical analyses of water of ornamental fish basins.

\begin{tabular}{lllllll}
\hline Element & $\mathbf{M n}$ & $\mathbf{C u}$ & $\mathbf{F e}$ & $\mathbf{K}$ & $\mathbf{P}$ & $\mathbf{N}$ \\
\hline Conc.ppm & 0.05 & 0.25 & 0.02 & 27.7 & 7.8 & 29.4 \\
\hline
\end{tabular}

Table (2). Effect of Irrigation by Drainage Water of Ornamental Fish Basins, Mg foliar spray and their interaction on the Growth Parameters of Potus Plants (Means of successive two seasons).

\begin{tabular}{|c|c|c|c|c|c|c|c|c|c|}
\hline \multirow{2}{*}{$\frac{\text { Treatments }}{100 \%(\mathrm{DWOFB})}$} & \multicolumn{2}{|c|}{ Plant height (cm) } & \multirow{2}{*}{$\frac{\text { No. of leaves }}{5.00}$} & \multicolumn{2}{|c|}{ Stem diameter $(\mathrm{cm})$} & \multicolumn{2}{|c|}{ Leaves Fresh Weight (g) } & \multicolumn{2}{|c|}{ Leave dry Weight (g) } \\
\hline & 39.50 & a & & 0.77 & $\mathrm{a}$ & 2.37 & a & 1.47 & a \\
\hline $75 \%(\mathrm{DWOFB})+25 \% \mathrm{TW}$ & 37.17 & $\mathrm{a}$ & 4.50 & 0.67 & $\mathrm{a}$ & 2.08 & $a b$ & 1.31 & $\mathrm{~b}$ \\
\hline $50 \%(\mathrm{DWOFB})+50 \% \mathrm{TW}$ & 32.67 & $\mathrm{~b}$ & 4.50 & 0.52 & $\mathrm{~b}$ & 1.74 & $\mathrm{~b}$ & 1.02 & $\mathrm{c}$ \\
\hline LSD at $\alpha 0.05$ level & 2.802 & & N.S & 0.134 & & 0.451 & & 0.022 & \\
\hline MFFR1 (25 ppm) & 34.56 & $\mathrm{~b}$ & 4.33 & 0.54 & $\mathrm{~b}$ & 1.87 & $\mathrm{~b}$ & 1.07 & $\mathrm{~b}$ \\
\hline MFFR2 (50 ppm) & 38.33 & $\mathrm{a}$ & 5.00 & 0.76 & $\mathrm{a}$ & 2.25 & a & 1.46 & a \\
\hline LSD at $\alpha 0.05$ level & 2.258 & & N.S & 0.103 & & 0.222 & & 0.052 & \\
\hline $100 \%$ DWOFB 1 x MFFR1 & 38.33 & $\mathrm{a}$ & 4.67 & 0.70 & & 2.24 & $a b$ & 1.32 & $\mathrm{~b}$ \\
\hline $100 \%$ DWOFB1 x MFFR2 & 40.67 & $\mathrm{a}$ & 5.33 & 0.83 & & 2.50 & a & 1.62 & a \\
\hline 75\%DWOFB2+25\%TW x MFFR1 & 33.33 & $\mathrm{~b}$ & 4.33 & 0.50 & & 2.06 & $\mathrm{~b}$ & 1.05 & $\mathrm{~d}$ \\
\hline $75 \%$ DWOFB2+25\%TW x MFFR2 & 41.00 & $\mathrm{a}$ & 4.67 & 0.83 & & 2.10 & $\mathrm{~b}$ & 1.58 & a \\
\hline $50 \%$ DWOFB3+50\% TW x MFFR1 & 32.00 & $\mathrm{~b}$ & 4.00 & 0.43 & & 1.32 & $\mathrm{c}$ & 0.86 & $\mathrm{e}$ \\
\hline $50 \%$ DWOFB3+50\%TW x MFFR 2 & 33.33 & $\mathrm{~b}$ & 5.00 & 0.60 & & 2.16 & $a b$ & 1.19 & $\mathrm{c}$ \\
\hline LSD at $\alpha 0.05$ level & 3.911 & & N.S & N.S & & 0.384 & & 0.089 & \\
\hline
\end{tabular}

Table (2). Continue.

\begin{tabular}{|c|c|c|c|c|c|}
\hline \multirow{2}{*}{$\begin{array}{l}\text { Treatments } \\
100 \%(\mathrm{DWOFB})\end{array}$} & \multicolumn{2}{|c|}{ Leaf area $\left(\mathrm{cm}^{2}\right)$} & \multicolumn{2}{|c|}{ Carbohydrates (\%) } & \multirow{2}{*}{$\begin{array}{l}\text { Root length (cm) } \\
34.50\end{array}$} \\
\hline & 42.17 & a & 9.16 & $\mathrm{a}$ & \\
\hline $75 \%(\mathrm{DWOFB})+25 \% \mathrm{TW}$ & 40.17 & $\mathrm{~b}$ & 8.39 & $\mathrm{a}$ & 29.33 \\
\hline $50 \%(\mathrm{DWOFB})+50 \% \mathrm{TW}$ & 34.33 & $\mathrm{c}$ & 5.15 & $\mathrm{~b}$ & 29.83 \\
\hline LSD at $\alpha 0.05$ level & 1.772 & & 1.018 & & N.S \\
\hline MFFR1 (25 ppm) & 32.89 & $\mathrm{~b}$ & 7.34 & & 32.11 \\
\hline MFFR2 (50 ppm) & 44.89 & a & 7.79 & & 30.33 \\
\hline LSD at $\alpha 0.05$ level & 2.732 & & N.S & & N.S \\
\hline 100\% DWOFB1 x MFFR1 & 30.67 & d & 5.76 & d & 29.00 \\
\hline $100 \%$ DWOFB1 x MFFR2 & 53.67 & a & 12.55 & a & 40.00 \\
\hline 75\%DWOFB2+25\%TW x MFFR1 & 36.00 & c & 9.44 & $\mathrm{~b}$ & 35.33 \\
\hline $75 \%$ DWOFB2+25\%TW x MFFR2 & 44.33 & $\mathrm{~b}$ & 7.35 & $\mathrm{c}$ & 23.33 \\
\hline $50 \%$ DWOFB3+50\%TW x MFFR1 & 32.00 & $\mathrm{~cd}$ & 6.81 & $\mathrm{c}$ & 32.00 \\
\hline 50\%DWOFB3+50\% TW x MFFR 2 & 36.67 & $\mathrm{c}$ & 3.49 & e & 27.67 \\
\hline LSD at $\alpha 0.05$ level & 4.733 & & 0.935 & & N.S \\
\hline
\end{tabular}

The means followed by the same alphabetical letters were not significantly different at the probability level of 0.05 .

DWFB: Drainage Water of ornamental Fish Basins, TW: Tap Water, MFFR: Magnesium Foliar Fertilizer Rate 
Table (3). Effect of Irrigation by Drainage Water of Ornamental Fish Basins, Mg foliar spray and their interaction on the Chemical constituents of Potus Plants (Means of successive two seasons).

\begin{tabular}{|c|c|c|c|c|c|c|c|c|}
\hline \multirow{2}{*}{$\begin{array}{l}\text { Treatments } \\
100 \% \text { (DWOFB) }\end{array}$} & \multicolumn{2}{|c|}{ Chlorophyll (a) } & \multicolumn{2}{|c|}{ Chlorophyll (b) } & \multicolumn{2}{|c|}{ Chlorophyll $(\mathbf{a}+\mathbf{b})$} & \multicolumn{2}{|c|}{ Carotinoids } \\
\hline & 0.83 & $\mathrm{a}$ & 0.25 & & 1.08 & $\mathrm{a}$ & 0.41 & $\mathrm{a}$ \\
\hline $75 \%$ (DWOFB) $+25 \% \mathrm{TW}$ & 0.77 & $\mathrm{~b}$ & 0.26 & & 1.03 & $\mathrm{~b}$ & 0.36 & $\mathrm{~b}$ \\
\hline $50 \%(\mathrm{DWOFB})+50 \% \mathrm{TW}$ & 0.64 & $\mathrm{c}$ & 0.24 & & 0.88 & $\mathrm{c}$ & 0.31 & $\mathrm{c}$ \\
\hline LSD at $\alpha 0.05$ level & 0.009 & & N.S & & 0.009 & & 0.010 & \\
\hline MFFR1 (25 ppm) & 0.66 & $\mathrm{~b}$ & 0.17 & $\mathrm{~b}$ & 0.83 & $\mathrm{~b}$ & 0.35 & $\mathrm{~b}$ \\
\hline MFFR2 (50 ppm) & 0.83 & $\mathrm{a}$ & 0.33 & $\mathrm{a}$ & 1.16 & $\mathrm{a}$ & 0.38 & $\mathrm{a}$ \\
\hline LSD at $\alpha 0.05$ level & 0.006 & & 0.004 & & & 0.008 & 0.005 & \\
\hline $100 \%$ DWOFB $1 \times$ MFFR 1 & 0.54 & $\mathrm{f}$ & 0.03 & $\mathrm{e}$ & 0.57 & $\mathrm{f}$ & 0.32 & $\mathrm{c}$ \\
\hline $100 \%$ DWOFB $1 \times$ MFFR2 & 1.11 & $\mathrm{a}$ & 0.47 & $\mathrm{a}$ & 1.58 & a & 0.50 & $\mathrm{a}$ \\
\hline $75 \%$ DWOFB2+25\%TW x MFFR1 & 0.83 & $\mathrm{~b}$ & 0.29 & $\mathrm{~b}$ & 1.12 & $\mathrm{~b}$ & 0.40 & $\mathrm{~b}$ \\
\hline $75 \%$ DWOFB $2+25 \%$ TW x MFFR2 & 0.72 & $\mathrm{c}$ & 0.22 & $\mathrm{c}$ & 0.94 & $\mathrm{~d}$ & 0.32 & $\mathrm{c}$ \\
\hline $50 \%$ DWOFB3+50\%TW x MFFR 1 & 0.61 & $\mathrm{e}$ & 0.20 & $\mathrm{~d}$ & 0.80 & $\mathrm{e}$ & 0.33 & $\mathrm{c}$ \\
\hline $50 \%$ DWOFB3+50\%TW x MFFR 2 & 0.67 & $\mathrm{~d}$ & 0.29 & $\mathrm{~b}$ & 0.96 & $\mathrm{c}$ & 0.30 & $\mathrm{~d}$ \\
\hline LSD at $\alpha 0.05$ level & 0.011 & & 0.007 & & 0.013 & & 0.009 & \\
\hline
\end{tabular}

The means followed by the same alphabetical letters were not significantly different at the probability level of 0.05 .

DWFB: Drainage Water of ornamental Fish Basins, TW: Tap Water, MFFR: Magnesium Foliar Fertilizer Rate

\section{References}

[1] Abdelraouf R. E. and Hoballah E. M. (2014b). Impact of irrigation systems, fertigation rates and using drainage water of fish farms in irrigation of potato under arid regions conditions. International Journal of Scientific Research in Agricultural Sciences. 1(5): 67-79.

[2] Abdelraouf, R. E., hoballah, E and Horia M. A. (2014a). Ruse of drainage water of fish ponds in Soybean cultivation under sprinkler irrigation system. International Journal of plant and soil Science. 3 (6):644 - 658.

[3] Abdelraouf R. E.; Hussein M.M.; Abd Elal M., Wahba S. A., and Hozayn M. (2014c). Sustainable impact from using drainage water of fish farms in irrigation of groundnut. Middle East Journal of Agriculture Research. 3(4): 1104-1111.

[4] Cosmas O. M.; Dominic O.; Chuk W. Ofar R.;O. Onwuka J and BernadetteI.(2014).Organic/inorganic leaf amaranth production: the case of poultry manure, fish effluent and NPK fertilizer.

[5] Cottenie A.; Verloo M.; Kieken L.; Veighe G. and Camerlyneck R. (1982). Chemical analysis of plant and soil laboratory of analytical agrochemistry. Univ.Ghent.Belgium. 100-129.

[6] Ebong,V. M. Ebong, (2006).Demond of fertilizer technology by small holder crop farmers for sustainable agricultural development in AKWa, Ibom state,Nigeria.Int.I.Agric.Biol.(8):728-730.

[7] Elnwishy N.; Saleh M. and Zalat S. (2006).Combating desertification through fish farming. The future of dryland Proceedings of the International Scientific conference on desertification UNESCO.

[8] El-MaghrabyT.A.(2004).Effect of wheat grain soaking in some micronutrient solutions on crop production under rainfall condition. Egyptian J.Soil Sci. 44(3):429-440.
[9] El-Met.A.E.;Safina S.A.; Abdalla F.E. and Sara El-Sawy S.A. (2011).Effect of Magnesium Sulphate and Copper Sulphate Foliar Application on Wheat Under Sandy Soil Conditions.Egypt.J.Agron.33(1):67-81.

[10] James ER.; Michael PM. and Thomasn ML. (2006). Recirculating aquaculture tank production systems: Aquaponics-Integrating Fish and Plant Culture SRAC Publication No. 454.

[11] Johnson,W." A Review of factprs Affecting Plant Growth" Agrikhalsa:What's New.29Nov2 http:// agrikhalsa-tripod.com/plant growth.htm

[12] Khan M.A.;Shaukat S.S.H. and Jabeen S. (2010).Irrigation of Sorghum crop with waste stabilization pond effects, Growth and yield responses. Pakistan journal of botany. 42(3):1665-1674.

[13] Kumar R.; Mehrotra N.K.; Nautiyal B.D.; Kumar P. and Singh P.K. (2009).Effect of copper on growth,yield and concentration of $\mathrm{Fe}, \mathrm{Mn}, \mathrm{Zn}$ and $\mathrm{Cu}$ in wheat plants ( Triticum aestivum L.).J. of Environmental Biology.30 (4):485-488.

[14] Rahmanng and Aksoyu (Eds.) (2014).Proceeding of the $4^{\text {th }}$ ISOFAR Scientific Confrance. Building Organic Bridges at Organic World Congress, 13-15 Oct, Instanbul, Turkey (Eprint ID 23126).

[15] Rakocy J. E.; Baily D. S.; Shultz R.; Charlie T. and Eric S. (2013).Update on Tilpia and Vegetable production in the UV1 Aquaponic System. University of the Virgin Islands Agricultural Experiment Station. Retrieved 11 March.

[16] Snedecor G.W. and Cochran W.G. (1982). Statistical Method.7th edition, Iawa State Univ., Press. Ames, Iawa, U.S.A: $325: 330$.

[17] Zeidan M.S. and Nofal O.A. (2003).Effect of urea on the efficiency of spraying iron, manganese, zinc and copper on wheat. Egypt.J.Agron.24, 121-131. 